\title{
Nacionalismos en la pintura de Francisco de Goya
}

\author{
Helmut C. Jacobs*
}

Nacionalismos en la pintura de Francisco de Goya

\section{Resumen}

Se analizan las obras de Goya El dos de mayo de 1808 y El tres de mayo de 1808 en cuanto a la representación de nacionalismos e imágenes del enemigo. Se mostrará que a Goya no le interesaba la confrontación de las dos naciones, la francesa y la española. Por el contrario, evitó subversivamente la confrontación de dos enemigos en tiempo de guerra mediante ciertos mensajes ambiguos, con los cuales intentó producir dos obras de arte que deberían expresar de forma universal el anhelo de paz y el rechazo a la violencia y la guerra. La escena con los mamelucos en la primera pintura, una alusión a la Reconquista, da al tema una dimensión histórica. El segundo lienzo, con sus indicios religiosos, sirve a Goya como refutación de la imagen del enemigo en el contexto de la leyenda negra: aquí los españoles no son los conquistadores que aniquilan a las otras naciones, sino las víctimas. El análisis de la metáfora de la luz de la segunda pintura mostrará que los franceses ya no representan la Ilustración y la innovación, sino que el pueblo español acoge y desarrolla las ideas ilustradas porque está dispuesto a luchar por su autonomía y libertad, aun a costa de su propia existencia.

\section{Nationalisms in the Painting of Francisco de Goya}

\section{Abstract}

This paper examines Goya's paintings The Second of May 1808 and The Third of May 1808 with regard to the representation of nationalism and images of the enemy. Goya had no interest in the confrontation between the French and Spanish nations, in fact, subversively, he evades this by creating certain ambiguous messages, and seeking to express with these two paintings a universal longing for peace and the rejection of violence and war. The scene with the Mamluks in the first painting refers to the Reconquista, thus giving the topic a historical dimension, whereas the second painting contains several religious references which Goya uses to disprove the image of the enemy represented by the Black Legend: here the Spanish are victims, not conquerors oppressing the other European nations. The light imagery of the second painting suggests that France no longer represents the Enlightenment and innovation, but that the realization of the corresponding ideals is now the task of the Spanish people, who are ready to fight for their legitimate claim to autonomy and liberty.

\footnotetext{
* Este trabajo se enmarca en el proyecto de investigación ACAF/ART IV «Cartografías analíticas, críticas y selectivas del entorno artístico y monumental del área mediterránea en la edad moderna» (HAR2015-66579-P), financiado por el Ministerio de Economía y Competitividad.
} 
JACOBS, H.C., «Nacionalismos en la pintura de Francisco de Goya», Acta/Artis. Estudis d'Art

Modern, 4-5, 2016-2017, págs. 55-75

PALABRAs Clave: El dos de mayo de 1808, El tres de mayo de 1808, nacionalismos, imágenes del enemigo, leyenda negra, metáfora de la luz en la Ilustración

KEYwORDS: The Second of May 1808, The Third of May 1808, nationalism, images of the enemy, Black Legend, light imagery of the Enlightenment

La investigación actual sobre la época de la Ilustración se focaliza cada vez más intensamente en los cambios históricos de la percepción cultural de las naciones y, en este contexto, es de particular interés también la historia de las relaciones culturales entre los países europeos y la Península ibérica, hasta ahora más bien tratada marginalmente. Así, en este trabajo se utilizarán los nuevos métodos de la imagología, es decir, la investigación de las imágenes, de los prejuicios o clichés que se forman en una determinada cultura ante otra cultura extranjera. Además, la formación de la identidad de una nación frente a otra puede ser analizada desde la perspectiva de la imagología particularmente cuando la construcción y representación de diferentes nacionalismos son el resultado de un enfrentamiento directo de dos naciones, por ejemplo, en el caso de confrontaciones bélicas. Desde este punto de vista metodológico y mediante conceptos imagológicos, se analizarán dos de las más célebres obras del arte español: El dos de mayo de 1808 y El tres de mayo de 1808, de Francisco de Goya, en las cuales está representada la violenta confrontación entre los representantes de dos naciones, la española y la francesa. ${ }^{1}$ Los dos lienzos se analizarán en relación con la escenificación y la representación de las nacionalidades, del poder y de la violencia. Ambas obras no solo son imágenes icónicas del arte de Goya sino que son, junto con los Caprichos, las que han provocado una mayor cantidad de interpretaciones, a menudo muy diferentes y también controvertidas, y han tenido un amplio impacto en los artistas posteriores de todas las disciplinas: en el campo de las artes visuales y el cine, así como en todos los géneros de la literatura (teatro, poemas ecfrásticos, novelas, ensayos, artículos periodísticos, etc.). Uno de los ejemplos más recientes de su recepción se encuentra en un fragmento de la autobiografía Le lièvre de Patagonie. Mémoires (París, 2009) de Claude Lanzmann (Bois-Colombes, 1925), periodista y director de cine francés, célebre por sus películas documentales Pourquoi Israel (1973) y Shoah (1985). Lanzmann inserta las pinturas en una larga serie de atrocidades de guerra que incluyen el holocausto.

En el proceso de producción de las imágenes del enemigo en el marco de un conflicto bélico entre dos naciones no es necesario que el otro sea de hecho o verdaderamente un enemigo. Hay que distinguir entre la ficción y la realidad. Pero en el caso de los franceses que ocu-

1. Sobre las dos obras véase LAFuente Ferrari, E., Goya. El Dos de Mayo y Los fusilamientos. Barcelona: Juventud, 1946; Tüngel, R., Los fusilamientos del 3 de Mayo de Goya. Madrid-Cuenca: Alianza - Cero Ocho, 1981; THomAs, H., Goya. El Tres de Mayo de 1808. Barcelona - Buenos Aires - México: Grijalbo, 1980; BATICLE, J., «Les 2 et 3 mai 1808 à Madrid: Recherches sur les épisodes choisis par Goya», Gazette des Beaux-Arts, 116, 1462, 1990, págs. 185-200; NEUSCHÄFER, H.-J., «Goya und die Tragödie der spanischen Aufklärung. Die Bilder zum 2. und 3. Mai 1808», en Frank, C.; Hänsel, S., Spanien und Portugal im Zeitalter der Aufklärung. Internationales Symposium der Carl Justi-Vereinigung und des Forschungszentrums Europäische Aufklärung. Potsdam, 19.-22. Februar 1998. Fráncfort: Vervuert, 2002, págs. 451-458; Alía PlanA, J.M., Dos días de mayo de 1808 en Madrid, pintados por Goya. Madrid: Fundación Jorge Juan, 2004; Mena MARQUÉs, M.B.; MÜHLEMaurer, G.; Garrido Pérez, M.C.; García-Máiquez, J.; Mora Sánchez, E.; Quintana Calamita, E.; Quintanilla GaRRIDo, C., «Goya: el Dos y el Tres de mayo de 1808 en Madrid. Estudio y restauración», Boletín del Museo del Prado, 27, 45, 2009, págs. 129-149; MuÑoz MolinA, A., El atrevimiento de mirar. Barcelona: Galaxia Gutenberg, 2012, págs. 33-80; BLAS OrtegA, M. DE, «Los cuadros de fusilamientos en el siglo XIX. Una discusión de intenciones», Bellas Artes. Revista de Artes plásticas, Estética, Diseño e Imagen, 11, 2013, págs. 55-79; BuscH, W., «Das Pathos der Sinnlosigkeit. Moderne Geschichtserfahrung in Francisco Goyas “Erschießung der Aufständischen”", en FLECKNER, U. (ed.), Bilder machen Geschichte. Historische Ereignisse im Gedächtnis der Kunst. Múnich: Oldenbourg Wissenschaftsverlag, 2014, págs. 221-234. 
paron España en 1808, las cosas eran evidentes: estos eran verdaderos enemigos, eran percibidos como tales por los españoles y fueron combatidos enconadamente después del levantamiento de Madrid del 2 de mayo, en la larga y atroz Guerra de la Independencia. La imagen del enemigo que Goya concibió para sus dos obras presuponía ponerse a sí mismo en relación con el enemigo. Goya se vio obligado a reflejar intensamente su posición frente a la nación francesa, que antes de la ocupación de su país no consideraba un país enemigo, sino, bien al contrario, la nación modélica de la Ilustración y de la Revolución francesa que, como tal, le inspiraba gran simpatía, aun sin haber sido un revolucionario político. Lo que le interesaba como ilustrado español eran las ideas y los valores de la Ilustración francesa. Para la concepción de los dos lienzos era necesario digerir y esclarecer la contradicción y la tensión entre el elevado modelo de la Ilustración y la realidad actual, bárbara y cruel.

Ante este dilema, se plantea la cuestión de cuál fue la estrategia que Goya adoptó para pintar las dos obras sin desdecirse de sus convicciones y principios. Se mostrará que a Goya no le interesaba la confrontación de las dos naciones, la francesa y la española, como sucede en numerosos grabados y pinturas de otros artistas de la época sobre el levantamiento de los madrileños contra los franceses. De hecho, si se consideran las dos pinturas desde esta perspectiva, se pueden reconocer soluciones muy ingeniosas para evitar imágenes simplistas del enemigo mediante la producción de cierta ambivalencia y complejidad en el contenido y la estructura de los lienzos. La visualización o representación pictórica del enemigo intensifica la relación con este en una medida más grande y más estrecha que solamente el acto verbal de su designación e identificación como enemigo. ${ }^{2}$ Independientemente de si se trata de un acto verbal o una representación pictórica, la imagen del enemigo influye en la percepción, reduciendo la complejidad y las opciones de considerar la posición del otro. ${ }^{3}$ Así, la producción de una imagen del enemigo presupone normalmente la simplificación del otro. Para evitar el peligro de una simplificación tal, Goya elige la estrategia de generar complejidad, evitando cualquier toma de posición política, y, de esta manera, no elaboró las pinturas sobre el levantamiento del pueblo madrileño tomando partido por Fernando VII. ${ }^{4}$ Por el contrario, Goya evitó subversivamente la representación de la confrontación de dos enemigos en tiempo de guerra mediante ciertas señales y ciertos mensajes ambiguos, con los cuales intentó producir dos obras de arte que deberían expresar de forma universal el anhelo de paz y el rechazo de la violencia y la guerra. Esto se evidencia en la composición de cada obra en sí, pero también en ciertas referencias que uno puede observar mediante la comparación entre las dos pinturas.

\section{LOS HECHOS HISTÓRICOS DEL 2 Y 3 DE MAYO DE 1808}

En 1807 Napoleón Bonaparte (1769-1821) aprobó la acción militar estratégica de la posible ocupación de España con el pretexto de pasar por la Península ibérica con sus tropas para atacar Portugal -el aliado de su enemigo principal, Inglaterra-. Un requisito importante para el éxito de este proyecto fue la debilidad política de la casa real de los Borbones españoles. En contraste con Carlos III (1716-1788), un rey poderoso que gobernó desde 1759 hasta su muerte el 14 de diciembre de 1788, y bajo cuyo reinado las ideas y reformas ilustradas habían evolucio-

2. Münkler, H., Politische Bilder, Politik der Metaphern. Fráncfort: Fischer, 1994, pág. 22.

3. Ibidem, pág. 34 .

4. Barbé Coquelin de Lisle, G., «Goya et Napoléon», en Dufour, G. (ed.), Les Espagnols et Napoléon. Actes du colloque international d'Aix-en-Provence, 13, 14, 15 octobre 1983. Marsella: Jean Laffitte, 1984, pág. 178. 
nado favorablemente en España, el sucesor, su hijo Carlos IV, no tenía, ni mucho menos, la formación del padre. Tampoco la influencia de su esposa María Luisa (1751-1819) resultó ser ventajosa, y los reyes delegaron el poder en su favorito, Manuel de Godoy (1767-1851), quien gestionó, de hecho, los asuntos del gobierno realizando una función comparable a la ejercida por los validos de los Habsburgo en el siglo XVII. Fernando (1784-1833), futuro sucesor al trono e hijo mayor de Carlos IV, fue mantenido deliberadamente alejado de todos los asuntos gubernamentales tanto por sus padres como por Godoy, con la consecuencia de que el príncipe de Asturias se convirtió con el tiempo en la figura dominante de la oposición contra Godoy y su política, pero también contra sus padres. ${ }^{5}$ El 10 de diciembre de 1807 , las primeras tropas francesas entraron en España y ocuparon de forma sistemática todo el país, aunque inicialmente esta ocupación no se percibió como tal. La Iglesia vio en Napoleón un pilar del catolicismo, los nobles esperaban preservar sus privilegios y su posición social, y los militares estaban deslumbrados por los éxitos militares de Napoleón. ${ }^{6}$

Como consecuencia del motín de Aranjuez, un levantamiento contra Godoy y los reyes, ocurrido el 17 de marzo de 1808 e iniciado por Fernando y sus partidarios entre la nobleza descontenta, Carlos IV fue forzado dos días más tarde a abdicar en favor de su hijo mayor. ${ }^{7}$ Ya el 21 de marzo Carlos IV revocó su abdicación, lo que, sin embargo, no tuvo prácticamente consecuencias. ${ }^{8}$ El 23 de marzo, el general Joachim Murat (1767-1815), gran duque de Berg y yerno de Napoleón, entró con sus tropas en Madrid con un aparatoso desfile militar. ${ }^{9}$ La recepción de los madrileños fue amistosa puesto que consideraban a los franceses amigos y aliados y esperaban su apoyo contra Godoy y en favor de Fernando, que era muy popular en este momento. Cuando un día más tarde, el 24 de marzo, Fernando entró en la capital desde Aranjuez como nuevo rey de España, fue recibido con entusiasmo y celebrado por los madrileños. ${ }^{10}$ Murat no reconoció a Fernando como nuevo rey, pero trató, sin embargo, a sus padres de manera muy cortés. En abril, Napoleón ordenó al destituido Carlos IV y a su familia trasladarse a Bayona y los mantuvo allí recluidos junto con Godoy. El rey Fernando VII viajó el 10 de abril desde Madrid a Burgos para acudir al encuentro acordado previamente con Napoleón con el fin de lograr que este reconociera su gobierno, pero llegado allí Fernando solo recibió una invitación del emperador francés para trasladarse a Francia. Desafortunadamente, Fernando se desplazó al país vecino; fue capturado y obligado a abdicar y Murat se alzó con el poder en España.

Ya a lo largo del mes de abril, la percepción de los madrileños respecto a los franceses había cambiado debido, fundamentalmente, a los numerosos incidentes y abusos más o menos violentos infligidos a los ciudadanos de la capital por los soldados franceses. ${ }^{11}$ Ocasionalmente, también estos fueron violentamente atacados por los madrileños. Los franceses eran vistos, cada vez más, como invasores, creándose un clima general de desconfianza. El domingo 1 de mayo hubo claros indicios de cuán grandes eran las tensiones entre la población de la capital y las tropas de ocupación. ${ }^{12}$ Por un lado, los franceses distribuyeron un panfleto en el que se ponía de manifiesto el deseo de sustituir la casa real de los Borbones por un rey de la familia de Napoleón.

5. Martí Gilabert, F., El Motín de Aranjuez. Pamplona: Universidad de Navarra - Consejo Superior de Investigaciones Científicas, 1972, págs. 26-33.

6. Ibidem, págs. 47-48. Sobre los diversos aspectos de la imagen de Napoleón en España, véase DufouR, G. (ed.), Les Espagnols et Napoléon...

7. Alcalá Galiano describe los acontecimientos del Motín de Aranjuez en sus Memorias, publicadas en 1886. AlcALÁ Galiano, A., Obras escogidas de D. Antonio Alcalá Galiano [Campos, J. (ed.)]. Madrid: Atlas, 1955, vol. 1, págs. 325-329.

8. Martí Gilabert, F., El Motín..., págs. 218-232.

9. Ibidem, págs. 248-253. Véase el relato contemporáneo de José María Queipo de Llano: ToRENo, CONDE DE, Historia del levantamiento, guerra y revolución de España [Cueto, L.A. De (ed.)]. Madrid: Atlas, 1953, págs. 26-27.

10. Martí Gilabert, F., El Motín..., págs. 253-259.

11. Ibidem, págs. 63-86, 294-296 y 349-351.

12. Alía y Plana, J.M., "El primer lunes de mayo de 1808 en Madrid», Madrid, el 2 de mayo de 18o8. Viaje a un día en la historia de España. Madrid: Capital Europea de Cultura, 1992, págs. 115-116. 
Por el otro, una gran multitud se había congregado en la Puerta del Sol para insultar y abuchear a Murat, quien, cruzando la plaza, regresaba al mediodía con su comitiva de la misa dominical. ${ }^{13}$

En la mañana del 2 de mayo, hacia las ocho, ocurrió un incidente delante del Palacio Real. ${ }^{14}$ Doña María Luisa Josefina, hija de Carlos y reina de Etruria, partió sin obstáculos con su hijo Carlos Luis en un coche mientras que un segundo vehículo esperaba aún delante del palacio. José Blas Molina Soriano, ${ }^{15}$ maestro cerrajero de profesión y partidario de Fernando VII, dio la alerta al ver el segundo coche que esperaba: gritó que los franceses habían secuestrado al rey y que querían llevarse al infante Francisco de Paula (1794-1865). El infante, no obstante, salió al balcón de la residencia real ante la cual se hallaba la multitud enfurecida y, momentáneamente, logró apaciguarla. Un enviado de Murat — su ayudante de campo Auguste Le Lièvre de La Grange (1780-1726) - y sus compañeros fueron sometidos a un linchamiento, pero lograron escapar de un castigo mayor. La indignación de Murat provocó que ordenara disparar a la muchedumbre - lo que sucedió, efectivamente, hacia las diez de la mañana-, iniciándose la escalada decisiva del conflicto que desencadenó el violento levantamiento contra los franceses, que se extendió rápidamente desde el Palacio Real a diferentes lugares de la ciudad.

Los primeros enfrentamientos violentos con los soldados de infantería franceses, entre ellos un grupo de mamelucos situados en la Puerta del Sol, tuvieron lugar poco después de las once. En las calles, los soldados franceses eran, inicialmente, inferiores en número a la muchedumbre que arremetía contra ellos. A pesar de su rudimentario armamento — palos, cuchillos y escopetas-, los insurrectos madrileños atacaron a los jinetes mamelucos. Algunos intentaron llegar a las espaldas de los caballos, agrediendo por detrás a los jinetes, otros se agazaparon debajo de los animales para abalanzarse sobre ellos con sus puñales.

Dos oficiales españoles, Luis Daoíz y Torres $(1787-1808)^{16}$ y Pedro Velarde de Santiyán (1779-1808), ${ }^{17}$ se hicieron cargo de la dirección de los insurrectos y defendieron el Parque de Artillería de Monteleón arremetiendo contra los soldados franceses. ${ }^{18}$ Murieron junto a muchos de sus soldados y, posteriormente, fueron venerados como héroes por su valiente resistencia contra los franceses.

Hacia las dos de la tarde, el levantamiento había sido aplastado por las tropas francesas con la mayor severidad. ${ }^{19}$ En conjunto, la violenta lucha callejera se prolongó unas cinco horas y se cobró muchas víctimas civiles, entre ellas mujeres y numerosos niños y adolescentes. ${ }^{20}$

Como venganza por la muerte de los soldados franceses, Murat ordenó que se instituyeran tribunales militares para que juzgaran y castigaran inmediatamente a los ciudadanos de Madrid que hubieran sido capturados con armas de cualquier tipo. Además, publicó una orden del día en la que se especificaba que todos aquellos ciudadanos que estuvieran en posesión de armas deberían ser fusilados. ${ }^{21}$ Las detenciones de los ciudadanos madrileños fueron percibidas, con

13. Sobre este incidente en la Puerta del Sol, véase ToReno, Conde DE, Historia del levantamiento..., pág. 43. También José Mor de Fuentes (1762-1848) estaba en ese momento en la Puerta del Sol. ArTolA, M. (ed.), Memorias de tiempos de Fernando VII. Madrid: Atlas, 1957, pág. 385.

14. Sobre el transcurso del levantamiento del 2 de mayo de 1808, véase PÉREZ DE GuZMán y Gallo, J., El dos de Mayo de 1808 en Madrid. Madrid: Establecimiento Tipográfico Sucesores de Rivadeneyra, 1908, págs. 372-416; MARTí GILABERT, F., El Motín..., págs. 386-395; Alía y Plana, J.M., «El primer lunes...», págs. 116-137; Demange, C., El Dos de Mayo. Mito y fiesta nacional (1808-1958). Madrid: Marcial Pons - Centro de Estudios Políticos y Constitucionales, 2004; GARCÍA FuERTES, A., Dos de Mayo de 1808. El grito de una nación. Barcelona: Inédita, 2007.

15. En varias cartas Molina Soriano relata al rey Fernando VII su compromiso y sus actividades durante el levantamiento del 2 de mayo de 1808. Montón, J.C., La revolución armada del Dos de Mayo en Madrid. Madrid: Istmo, 1983, págs. 90-91 у 226-239.

16. Pérez de GuzMán y Gallo, J., El dos de Mayo..., pág. 680, núm. 257.

17. Ibidem, pág. 690, núm. 361.

18. Alía y Plana, J.M., «El primer lunes...», págs. 122-130.

19. Ibidem, pág. 130.

20. Pérez de GuZmán y Gallo, J., El dos de Mayo..., págs. 385-386, n. 1.

21. Esta orden se publica en el Diario de Madrid del 4 de mayo y en la Gazeta de Madrid del 6 de mayo. ALÍA Y PLANA, J.M., «El primer lunes...», págs. 130-131. 
razón, como actos arbitrarios, siendo valorados por los autores contemporáneos como una venganza furiosa de la potencia francesa usurpadora. Hay que tener en cuenta, además, que el aviso público se divulgó en un medio muy limitado, lo cual impidió a la población conocer su alcance. De hecho, fue detenido prácticamente cualquiera que tuviera un arma, sin haberse comprobado previamente su participación en el levantamiento. Estar en posesión de un cuchillo, algo muy frecuente en la época, se convirtió en motivo suficiente para proceder a la detención de su dueño. ${ }^{22}$

Las ejecuciones de los presos comenzaron hacia las tres de la tarde del 2 de mayo y continuaron hasta la madrugada del día siguiente en diferentes lugares: algunas en el Paseo del Prado, otras en los cuarteles de los franceses, en el Parque del Retiro y en la Montaña del Príncipe Pío. Con respecto a estas últimas, se conoce el número exacto de las víctimas. Las ejecuciones tuvieron lugar allí hacia las cuatro de la madrugada del 3 de mayo, antes del amanecer, disparándose, tres salvas en total. ${ }^{23}$ Allí fueron ejecutadas 43 personas — de 19 de las cuales se conoce la identidad,$-^{24}$ que fueron elegidas a suerte del grupo de los presos. ${ }^{25}$

No solo la arbitrariedad de las acciones acometidas por los franceses después del levantamiento causó indignación en la población, sino que fue sobre todo el nuevo tipo de ejecución en masa por un pelotón de fusilamiento, algo que nunca habían experimentado los españoles. Como otra crueldad de los franceses percibieron los españoles la orden de Murat que prohibía a los familiares de las víctimas recoger y enterrar inmediatamente los restos mortales de los ejecutados. Solo unos días después, el 7 de mayo, se permitió recoger de las calles de Madrid a los caídos, los cuerpos de los cuales estaban, por lo general, apilados frente a las fachadas de los edificios. Mientras tanto, los franceses ya habían recogido a sus víctimas sin demora. ${ }^{26}$ En el caso de los fusilados en la Montaña del Príncipe Pío, a los madrileños no se les permitió recoger los cadáveres de los fallecidos hasta una semana más tarde, el 12 de mayo. ${ }^{27}$ Fueron enterrados en el cementerio de San Antonio de la Florida, cerca de la Montaña del Príncipe Pío. ${ }^{28}$

El levantamiento del 2 de mayo tuvo consecuencias de largo alcance: para Napoleón los amargos años de lucha incesante durante la Guerra de la Independencia resultaron ser el principio del fin de su poder y, para España, el interregno napoleónico fue un paso decisivo hacia la separación de las colonias de la metrópoli. A lo largo del siglo XIX, cada vez más países declararon su independencia de España.

\section{La actitud ambivalente de Goya hacia Francia}

La relación entre Francia y España cambió absolutamente a lo largo del siglo XVIII y a comienzos del siglo XIx. Desde el gobierno del primer Borbón español, Felipe $\mathrm{V}$-después de la Guerra de Sucesión al inicio del siglo xviII-, Francia se convirtió en un referente para la política española y, desde mediados de siglo, con la Encyclopédie y los escritos de los philosophe, también en un modelo literario, filosófico y cultural para los ilustrados españoles. Inicialmente se mantuvo casi a ciegas el modelo francés, sin embargo, a partir de los años ochenta del siglo XVIII,

\footnotetext{
22. Ibidem, págs. 131-132.

23. Montón, J.C., La revolución..., pág. 137.

24. PÉrez de GuZmán y Gallo, J., El dos de Mayo..., págs. 447-448; Montón, J.C., La revolución..., pág. 176.

25. Ibidem, pág. 137.

26. Ibidem, pág. 141.

27. Idem; Alía Y Plana, J.M., «El primer lunes...», pág. 132.

28. Montón, J.C., La revolución..., págs. 13 y 175-182; APARISi LAPORTA, L.M., "Cementerio del Tres de Mayo», Revista Madrid Histórico, 9, 2007, págs. 35-42.
} 
aumentó tanto la visión crítica con respecto a Francia como la consciente introspección hacia la propia tradición española — muchos de los autores españoles se distanciaron de Francia, y del movimiento de la Ilustración francesa, como reacción a la imagen negativa y deformada de España que ofrecían los ilustrados franceses- $-{ }^{29}$ Entre los intelectuales españoles de entonces tuvo una repercusión muy negativa el debate que se generó a raíz del artículo sobre España de la Encyclopédie méthodique de 1782, escrito por Nicolas Masson de Morvilliers (1740-1789). Así, por ejemplo, Juan Sempere y Guarinos (1754-1830), en el segundo volumen de su Ensayo de una biblioteca española de los mejores escritores del reynado de Carlos III, de 1785, manifestó su distanciamiento respecto a Francia, que tanto para él, como antes, en la primera mitad del siglo, para Ignacio de Luzán (1702-1754) se consideraba modelo del buen gusto. ${ }^{30}$ Por lo demás, el desarrollo de la Ilustración en España se vio frenado debido a ciertas medidas en la política exterior e interior que se tomaron por miedo a las consecuencias y la influencia negativa de la Revolución francesa de 1789. Sobre todo entre 1793, año en que fueron guillotinados los reyes franceses, y la caída de Napoleón, la galofobia española fue muy acusada. ${ }^{31}$ El rechazo de la Revolución francesa se propagó con intensidad en la prensa española de la época. ${ }^{32}$ Así, los españoles atribuyeron a los franceses características como la frivolidad, la ligereza y la inconstancia, cuyas raíces reconocieron en el abandono del catolicismo y la anulación de toda afiliación religiosa. ${ }^{33}$ Tanto el artículo de Masson de Morvilliers, en el que opinaba que España no contribuyó en absoluto a la cultura europea, como la Revolución francesa causaron, pues, una fuerte galofobia. ${ }^{34}$ Finalmente, la invasión francesa por parte de las tropas napoleónicas, el levantamiento de los madrileños el 2 de mayo de 1808 y la Guerra de la Independencia terminaron abruptamente con todos los intentos de reforma y movimientos ilustrados en España.

Como artista convencido de las ideas de la Ilustración, Goya era principalmente francófilo. Francia había sido para él un modelo, según el cual se orientó durante mucho tiempo; y consideró muy positivamente los ideales de libertad e igualdad derivados de la Revolución francesa. Un indicio relevante que señala su proximidad al modelo francés se advierte en el sombrero de copa que Goya luce en su autorretrato del Capricho 1 (1799). En él, Goya no se presenta como artista sino como ciudadano de su época: sin un solo atributo relativo a su gremio, vestido con ropa de calle y sombrero de copa. Sin embargo, en 1799 el sombrero de copa no era solo un modo extraordinariamente moderno de cubrirse la cabeza — con el que Goya dejaba patente su conciencia de la moda-, sino, sobre todo, una expresión de su pensamiento liberal o incluso subversivo-revolucionario. ${ }^{35}$ El sombrero de copa derivó del de los puritanos o cuáqueros en Inglaterra a finales del siglo XVIII; a partir de ahí empezó a causar furor en Estados Unidos, desde donde fue reimportado a Europa como símbolo de las ideas liberales. Por lo tanto, y desde el punto de vista de sus contemporáneos, el sombrero de copa que aparece en el

29. FloecK, W., «Das Spanienbild der französischen Aufklärer und die spanische Ilustración», Iberoromania, 13, 1981, págs. 70-71.

30. SEMPERE y GuARINos, J., Ensayo de una biblioteca española de los mejores escritores del reynado de Carlos III. Madrid: Gredos, 1969 [1785], vol. 2, pág. XII.

31. Carnero, G., «La utilización del mito antinapoleónico en el primer romanticismo conservador español», en La Invasió Napoleònica. Economia, Cultura i Societat. Bellaterra: Universitat Autònoma de Barcelona, 1981, pág. 150.

32. Aymes, J.-R., «L'Espagne et le refus de la Révolution 1789-1785. Les thèmes de la campagne d'opinion», en VoveLLE, M. (ed.), L'image de la Révolution Française. Communications présentées lors du Congrès Mondial pour le Bicentenaire de la Révolution. Sorbonne, Paris, 6-12 juillet 1989. París-Oxford-Nueva York-Pekín-Fráncfort-Sidney-Tokio: Pergamon Press, 1990, vol. 1, págs. 660-667; VARELA, J., «Le peuple inconstant: l'opinion espagnole face à la France (1789-1808)», en VovELLE, M., L'image de la Révolution Française..., págs. 668-685.

33. LAfARga, F., «Regicidio y galofobia. Imágenes hispánicas de Luis XVI y María Antonieta», en SANTA, Á.; GINÉ, M.; PArra, M., 1793, Naixement d'un Nou Món a l'Ombra de la República. Lérida: Universitat de Lleida, 1995, págs. 509-520.

34. JütTner, S., «Die Gallophobie in Spanien - Stimulus für die Positivierung des Deutschlandbildes in der Presse des aufgeklärten Absolutismus?», en Häseler, J.; MeIER, A., Gallophobie im 18. Jahrhundert. Berlín: Berliner WissenschaftsVerlag, 2005, págs. 195-219.

35. Sobre la historia del sombrero de copa, véase Timidion, O., Der Hut und seine Geschichte. Eine kulturgeschichtliche Monographie. Viena-Leipzig: A. Hartleben's, 1914, págs. 58-66. 
autorretrato del Capricho 1 es, por una parte, una expresión de las convicciones burguesas liberales de Goya, y, por la otra, un atributo revolucionario, la manifestación de una voluntad extraordinariamente provocativa. ${ }^{36}$

Para Goya, la brutal ocupación de su país por las tropas napoleónicas en 1808 significó una desilusión tremendamente dolorosa. Respecto a la actitud francófila, que desde el siglo XIX se denomina afrancesamiento, es muy importante distinguir, metodológicamente, un afrancesamiento cultural y filosófico de un afrancesamiento político, que incluso se puede referir a la situación política diaria. Lo uno no implica necesariamente lo otro, sino que la incompatibilidad entre los pensamientos idealistas de la Ilustración francesa y la política real de Francia, cuyas consecuencias se pudieron sentir concretamente en la vida cotidiana de los españoles de la época, constituyó un enfrentamiento abismal que para muchos ilustrados españoles desembocó en un conflicto interior insalvable que se intensificó sobre todo entre 1808 y 1814.

Aun antes del regreso de Fernando VII, que fue reconocido como rey legítimo de España en el Congreso de Viena, Goya se esforzó - con éxito- para obtener la licencia oficial que le permitiera pintar unas obras sobre el tema del levantamiento de Madrid de 1808. Así lo expresó en una carta del 24 de febrero de 1814, dirigida al entonces gobierno provisional. El 14 de marzo siguiente Juan Álvarez Guerra (1770-1845) dio al secretario del Despacho de Hacienda la orden de proporcionar a Goya la financiación necesaria para la realización de las pinturas. ${ }^{37}$ Goya había cooperado con los representantes del gobierno francés - había trabajado para ellos como retratista-. Como afrancesado se encontraba en una situación precaria de la que, obviamente, quería liberarse con el encargo, ya que como pintor de Corte estaba subordinado al nuevo rey. En cuanto a su posición política, Goya profesó con los temas representados en El dos de mayo de 1808 y de El tres de mayo de 1808 no solo su patriotismo, sino también su lealtad a la casa real de los Borbones. Esta era la función protectora individual del encargo, con el que Goya quería encomendarse, como patriota leal, al nuevo gobierno de la Restauración y al rey Fernando VII.

Como artista que había servido a los respectivos representantes de gobiernos adversos, Goya no solo estaba inmerso en un conflicto político, sino que también se encontró ante un dilema artístico. Tenía que resolver cómo podía conciliar su mentalidad de ilustrado con el tema, elegido más o menos voluntariamente, del patriotismo español y de la representación del enemigo francés.

\section{LA REPRESENTACión ARTÍSTICA DE LA GUERRA DE LA INDEPENDENCIA EN LOS «DESASTRES DE LA GUERRA» DE GOYA}

Durante la Guerra de la Independencia Goya reaccionó sensiblemente ante los acontecimientos bélicos y sus amargas consecuencias; el pintor buscó y desarrolló nuevas formas de representar estas experiencias traumáticas y las atrocidades de la realidad a través de la expresión artística en la serie de grabados de los Desastres de la Guerra, que empezó probablemente en 1810. Sin que las personas pudiesen ser identificadas, todos los grabados tienen una relación directa con los acontecimientos contemporáneos de la Guerra de la Independencia. ${ }^{38}$ De una manera implacable, Goya representa los horrores de la guerra ejemplificándolos en una serie de seres anó-

36. Esa misma ambivalencia se observa también en el Capricho 30, en el que una figura de sonrisa maliciosa aparece representada con sombrero de copa.

37. GoYA, F. DE, Diplomatario [CANELlas López, Á. (ed.)]. Zaragoza: Librería General, 1981, págs. 485-486, núm. CXXIV.

38. Dufour, G., Goya durante la Guerra de la Independencia. Madrid: Cátedra, 2008. 


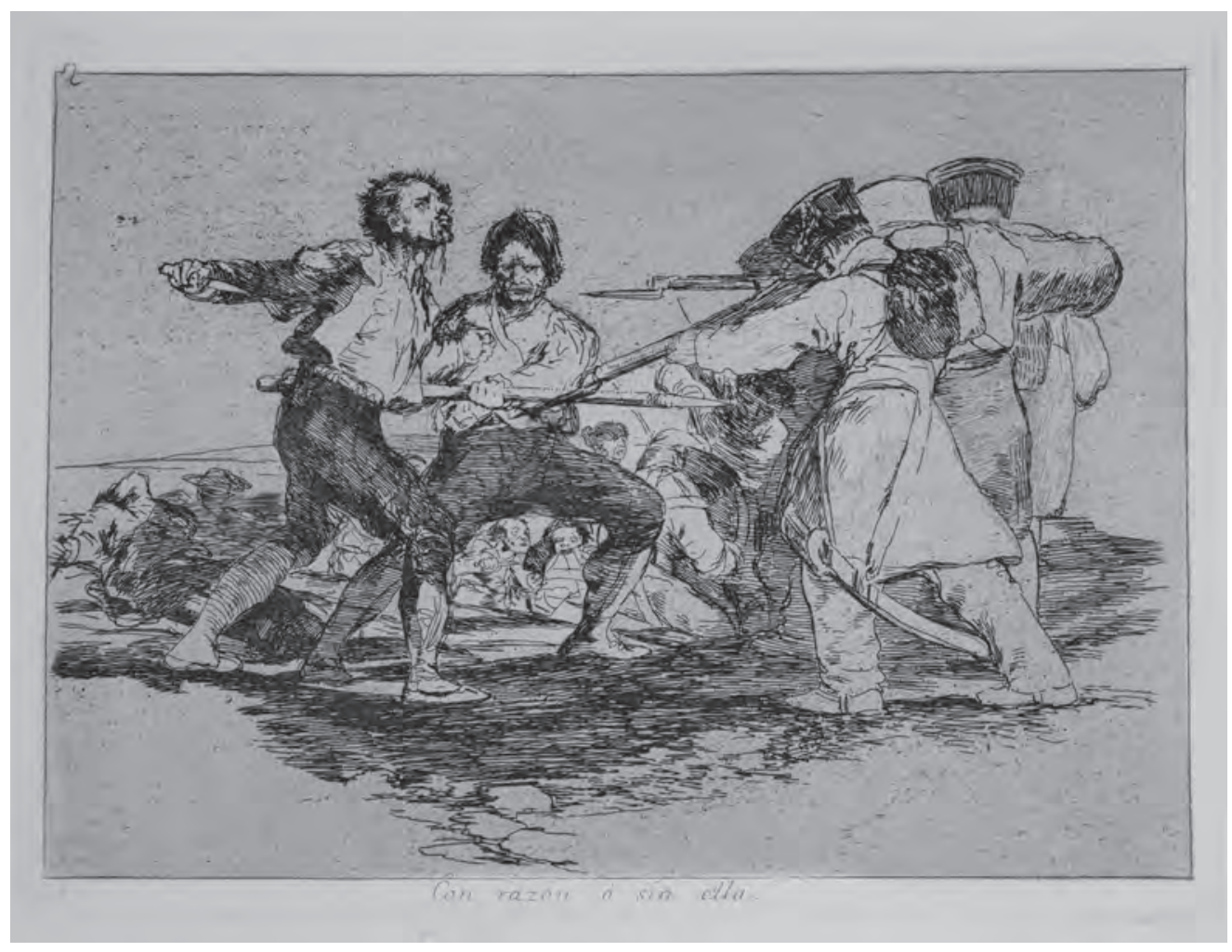

1. Francisco de Goya Desastres de la Guerra 2, c. 1810-1814, grabado, $24,8 \times 34,1 \mathrm{~cm}$. Museo Nacional del Prado, Madrid.

nimos, especialmente las víctimas de la población civil; representa violaciones, torturas, amenazas y homicidios ejecutados por los soldados franceses, pero también la venganza atroz y sin piedad de los españoles contra sus adversarios. La publicación de estos grabados durante la vida de Goya era casi impensable; por este motivo fue posteriormente, no antes de 1863, cuando la Academia de San Fernando de Madrid publicó la serie.

En cierto modo, algunos de los Desastres de la Guerra se corresponden con una preparación artística de las obras ulteriores de El dos de mayo de 1808 y El tres de mayo de 1808. Sobre todo existen similitudes tanto en la estructura como en el contenido entre los dos lienzos y algunos de los Desastres de la Guerra: el Desastres de la Guerra 2 («Con razón o sin ella») muestra a dos hombres con gestos desesperados inmediatamente antes de ser fusilados por varios soldados franceses (ilustración 1).

En el Desastres de la Guerra 26 («No se puede mirar») se representa un grupo de mujeres y hombres en la misma situación, con los cañones de los fusiles apuntados hacia ellos, desde el margen derecho del grabado (ilustración 2). También el Desastres de la Guerra 15 ( YY no hay remedio») es una escena de fusilamiento en la que las víctimas, atadas a palos, son ejecutadas por soldados franceses; a la derecha en primer plano yace un hombre asesinado (ilustración 3).

El fusilamiento de un hombre atado a un árbol, ejecutado por dos soldados, lo muestra el Desastres de la Guerra 38 («Bárbaros»), y el Desastres de la Guerra 22 («Tanto y más») presenta el resultado de las ejecuciones: un montón de cadáveres (ilustraciones 4 y 5).

Aunque Goya muestra el sufrimiento de las mujeres y los hombres como consecuencia de la guerra, esto no está representado en forma de propaganda ideológica, sino que la serie de los Desastres de la Guerra está caracterizada por su tratamiento no ideológico de amigos y enemigos. En muchos grabados de los Desastres de la Guerra está representada la muerte. En la mayoría de los casos Goya no muestra hechos heroicos, sino los acontecimientos atroces sucedidos al margen mediante seres individuales, ejemplificando, así, el sufrimiento en situaciones extremas concretas. 
2. Francisco

de Goya

Desastres

de la Guerra 26 ,

c. 1810-1814,

grabado,

$24,8 \times 34,1 \mathrm{~cm}$.

Museo Nacional del Prado,

Madrid.

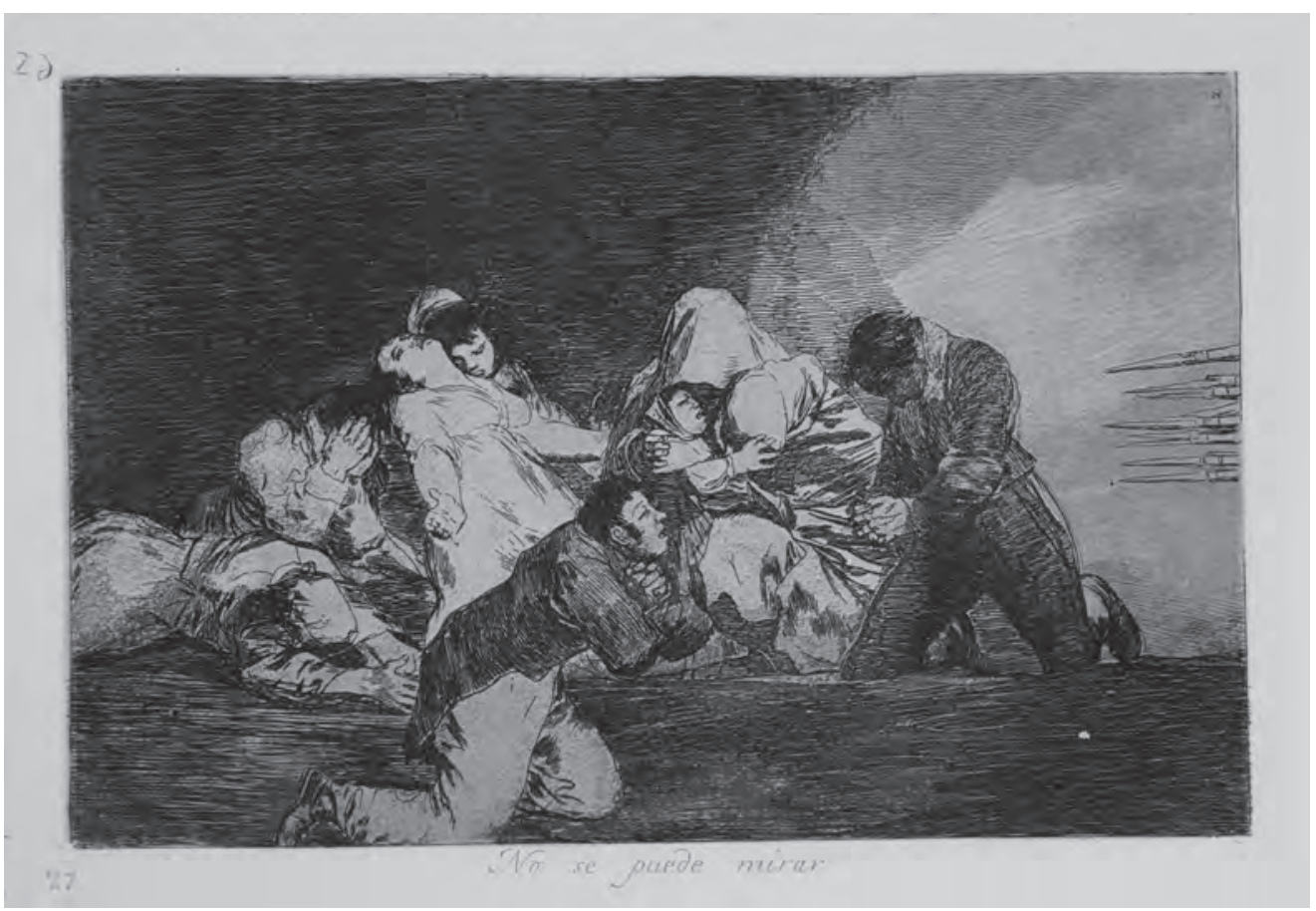

3. Francisco

de Goya

Desastres

de la Guerra 15,

c. 1810-1814,

grabado,

$24,8 \times 34,1 \mathrm{~cm}$.

Museo Nacional

del Prado,

Madrid.

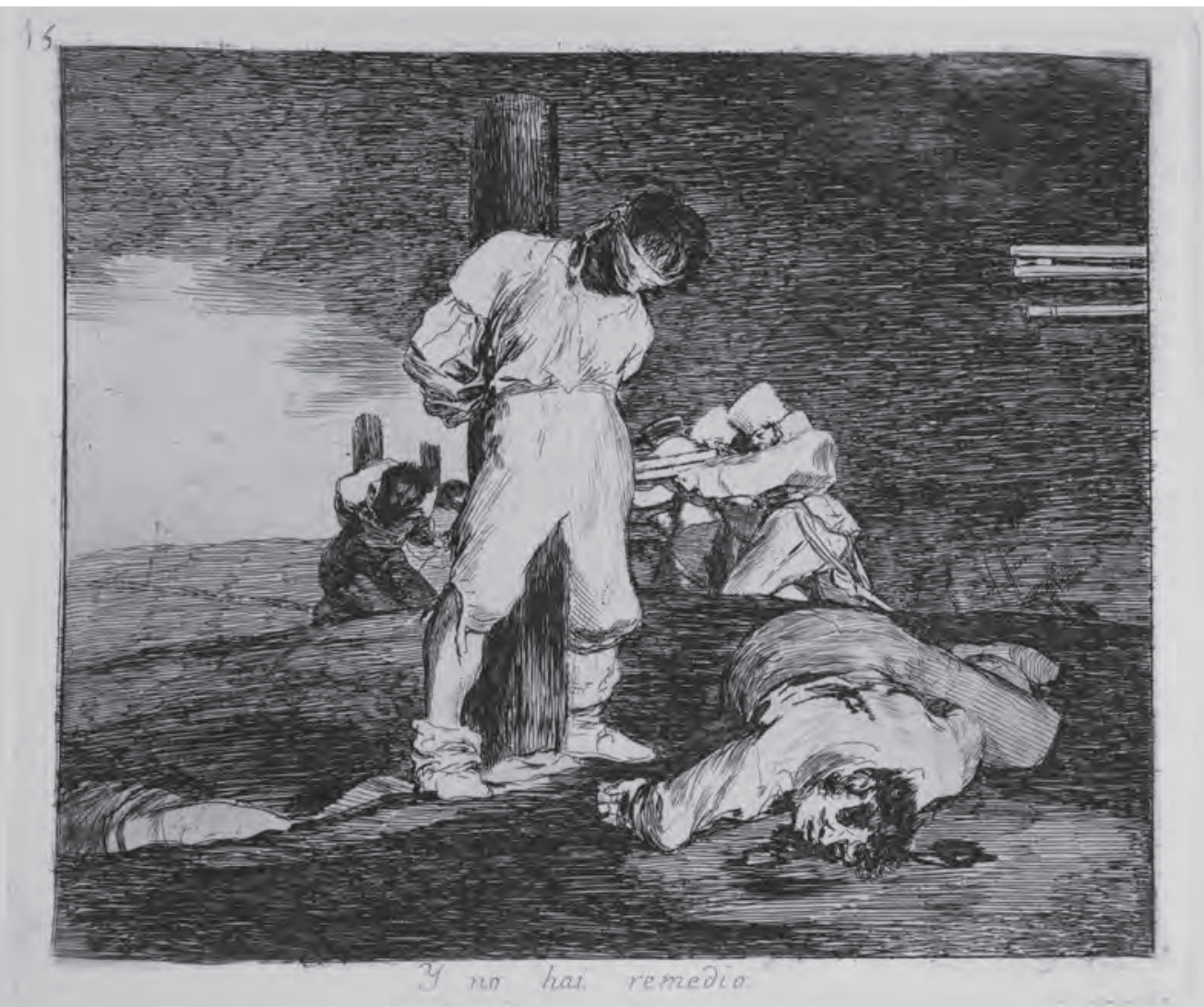




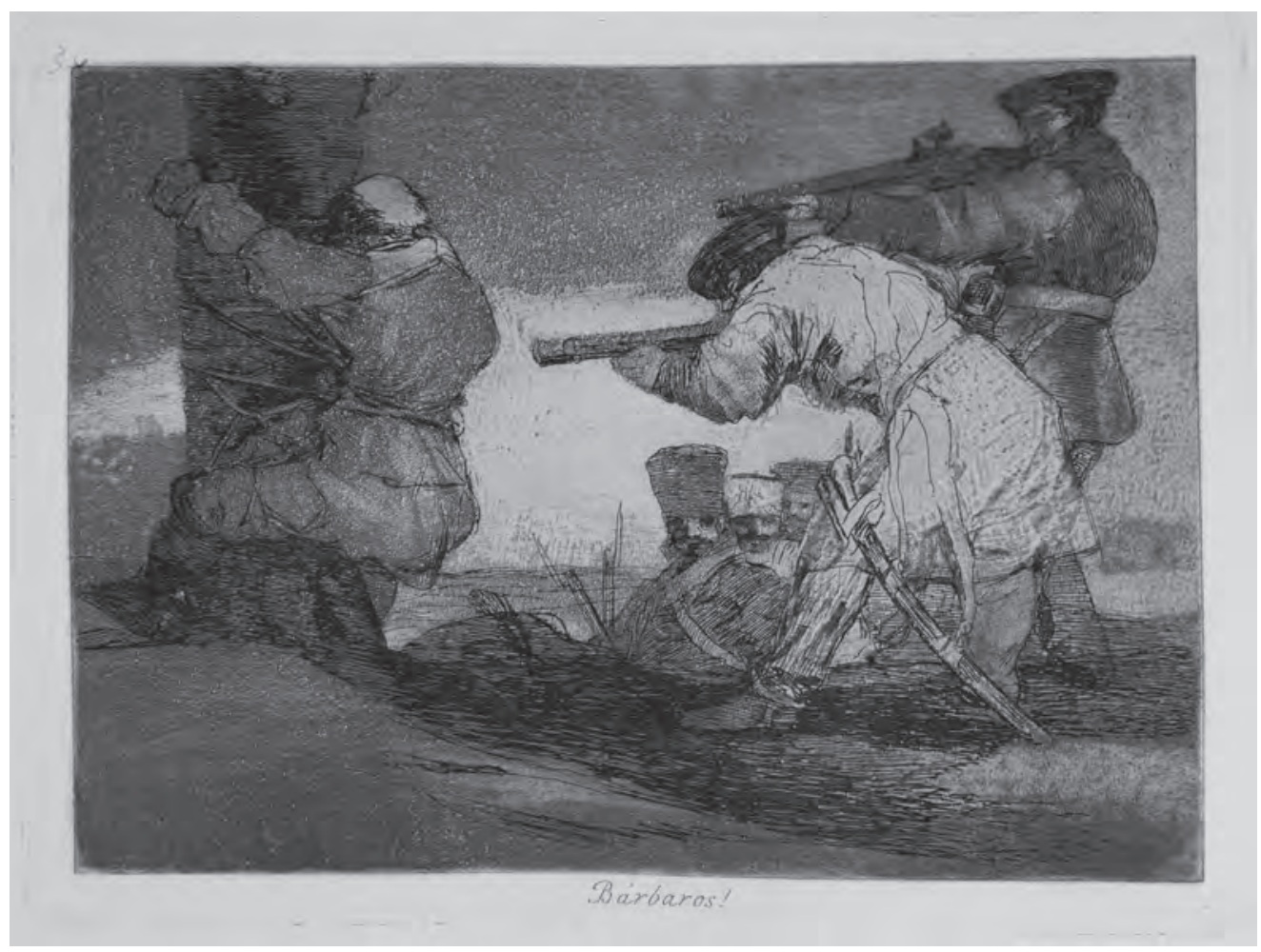

4. Francisco

de Goya

Desastres

de la Guerra 38,

c. 1810-1814,

grabado,

$24,8 \times 34,1 \mathrm{~cm}$.

Museo Nacional del Prado,

Madrid.

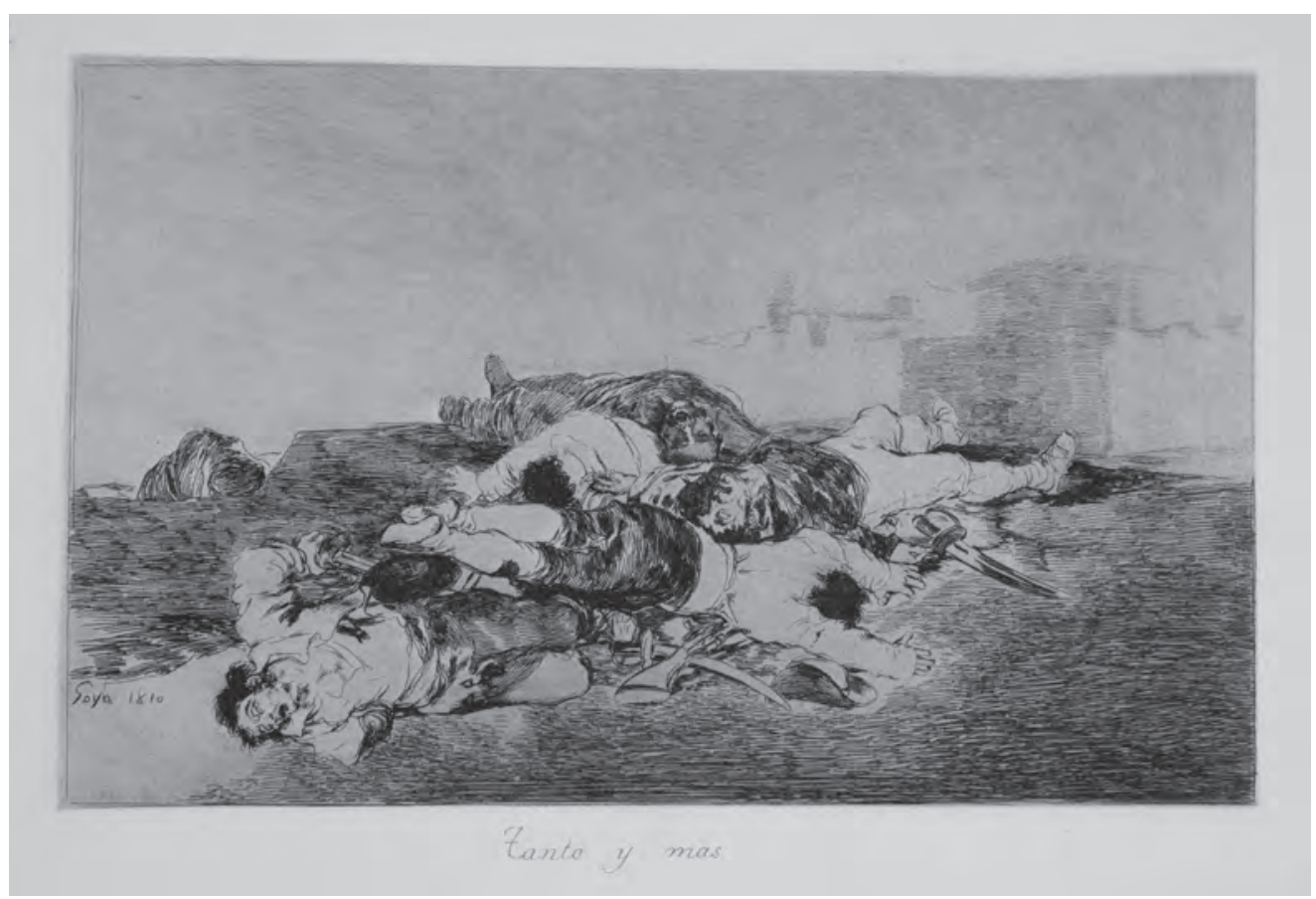

5. Francisco

de Goya

Desastres

de la Guerra 22,

c. 1810-1814

grabado,

$24,8 \times 34,1 \mathrm{~cm}$.

Museo Nacional del Prado,

Madrid.

La Guerra de la Independencia se escenifica como el permanente martirio del hombre. Su sufrimiento es universal e independiente de la pertenencia a uno de los bandos en contienda o a una nación, y Goya lo muestra en ambos lados, también en los soldados franceses que son brutalmente maltratados, combatidos y masacrados por mujeres y hombres españoles. Los Desastres de la Guerra son el primer paradigma, insuperado en su intensidad, de la represen- 
tación pictórica de la particularización de la guerra moderna en la que los individuos —o los grupos alrededor de un caudillo - saquean y violan. ${ }^{39}$ Los actos de guerra son ya tan difusos y carentes de toda moralidad que se puede hablar de una asimetría de la guerra y definir las acciones de la guerra como conflictos violentos asimétricos. ${ }^{40}$

\section{ÉCFRASIS DE «EL DOS DE MAYO DE 1808» Y «EL TRES DE MAYO DE 1808»}

A diferencia de los Desastres de la Guerra, que permanecieron como obras privadas y no publicadas en vida del artista, El dos de mayo de 1808 y El 3 de mayo de 1808 eran obras representativas de gran formato, destinadas al público (ilustración 6).

En El dos de mayo se presenta la acción de combate feroz en la Puerta del Sol. Se muestra la instantánea de una lucha desordenada, confusa y tumultuosa: una tropa de jinetes franceses y mamelucos, estos últimos vestidos a la moda oriental, con turbantes y pantalones bombachos rojos y armados con cimitarras y puñales. Los ciudadanos de Madrid, que arremeten con decisión y furia contra ellos, van solo armados con dagas y cuchillos y, a pesar de este insuficiente armamento, parecen tener ventaja sobre sus adversarios. Los soldados franceses y los mamelucos están huyendo ante los asaltantes españoles. Yacen muertos y heridos en el suelo.

A primera vista se trata de una escena de combate completamente arbitraria, que no parece estar dispuesta y escenificada de ninguna manera ventajosa, sin embargo fue exactamente planeada, organizada y cuidadosamente ejecutada. Las características innovadoras de la pintura son evidentes, comparándola con escenas de batallas tradicionales de la época. El espectador se enfrenta inmediatamente con la escena brutal, sin la posibilidad de escapar de esta impresión instantánea o de tomar una perspectiva distanciada, desde la cual, tradicionalmente, puede obtener una visión de conjunto sobre toda la batalla desde una posición elevada. Más bien al contrario, es una perspectiva de profundis, desde la cual el espectador — tanto si le gusta como si no- se ve involucrado en la acción del combate que está en pleno apogeo. En un realismo implacable, la escena muestra un episodio de guerra brutal en el que los enemigos anónimos, cuerpo a cuerpo, luchan a ultranza. No existe ningún centro en la pintura, como en los cuadros de batalla tradicionales en los que un señor de la guerra ordena a sus tropas (ilustración 7).

En El tres de mayo de 1808 está representada la trágica fase final del levantamiento: los fusilamientos en la Montaña del Príncipe Pío durante la madrugada del 3 de mayo, los cuales ya habían costado la vida a un primer grupo de presos españoles. No solo se representa un momento significativo para las siguientes víctimas, sino que es el peor momento posible: el justamente posterior a la orden de disparar e inmediatamente anterior a su ejecución, por lo que los condenados a muerte presencian el último momento de su vida justo antes de morir.

La figura central de la mitad izquierda es el hombre de la camisa blanca. Extendiendo sus brazos un instante antes de ser ejecutado por el pelotón de fusilamiento, no ve ninguna posibilidad de salvar su vida. El clérigo con la tonsura encorvado hacia delante mira al suelo y cruza las manos en oración. El hombre por encima de él mira despavorido en la dirección del pelotón de fusilamiento, pero no lo focaliza con los ojos muy abiertos, sino que mira por encima de él; el hombre situado justo detrás aprieta los puños y los pone sobre las sienes, mientras que otro hombre en el fondo se tapa los ojos con las manos.

39. MüNKLeR, H., Die neuen Kriege. Reinbek: Rowohlt, 2003

40. JANZING, G., «Bildstrategien asymmetrischer Gewaltkonflikte», Kritische berichte. Zeitschrift für Kunst-und Kulturwissenschaften, 33, 2005, págs. 21-35 (pág. 24). 


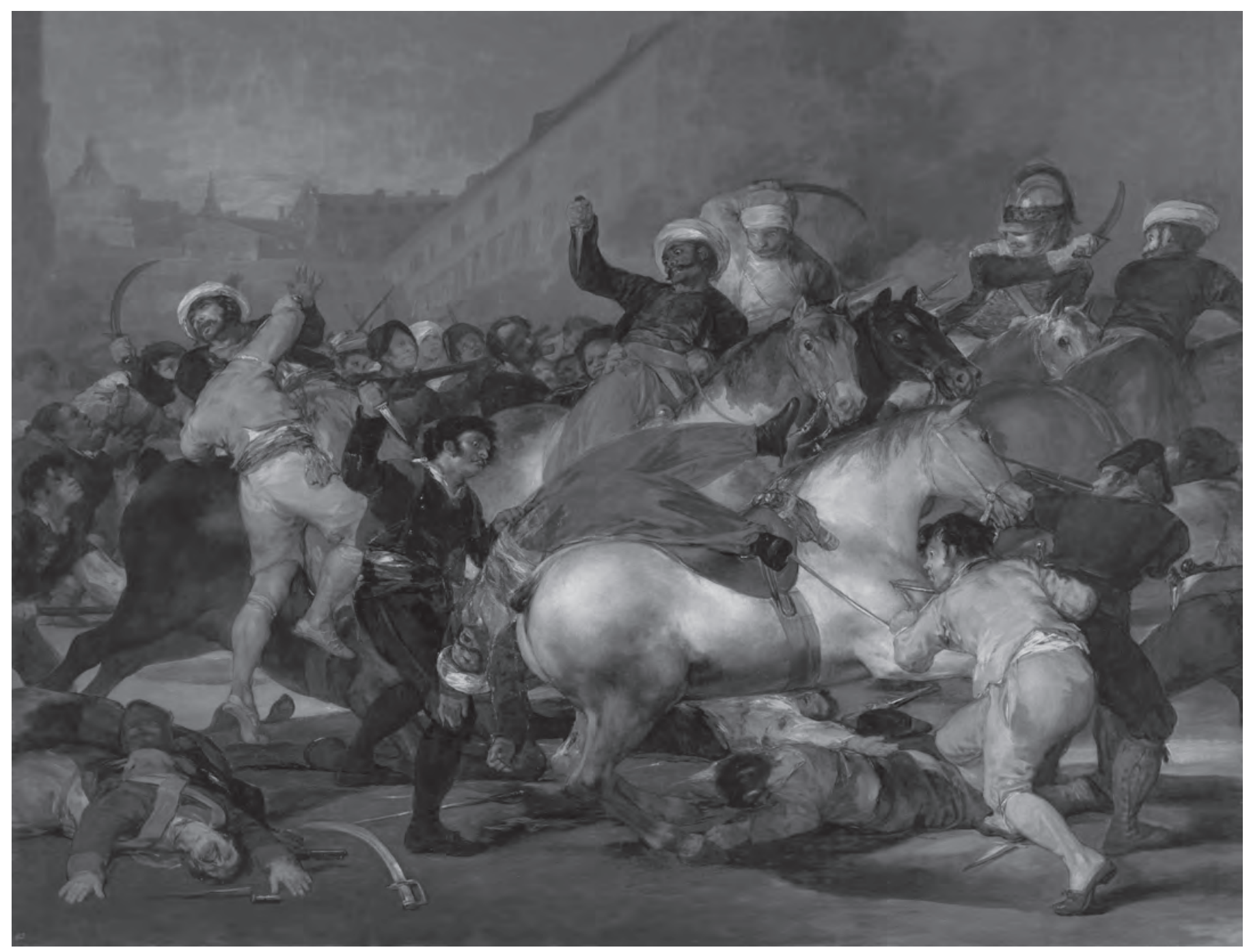

En el primer plano, delante del grupo de los hombres, yacen los recién fusilados, de cuyos cuerpos emana la sangre; claramente visible es el tiro en la cabeza del muerto, yacente en primer plano y circundado de un charco de sangre que brota de su cuerpo, quien extiende los brazos como si previamente hubiera tenido la misma actitud del hombre en pie de la camisa blanca. A la derecha, detrás de este, se encuentra un grupo de detenidos que serán los próximos en ser ejecutados. El primero de la cola se lleva las manos a la cara con el fin de escapar a la visión de la ejecución. El hombre a su izquierda, con una gorra o capucha sobre la cabeza, cierra la boca con sus manos, presumiblemente para reprimir un grito. Entre los dos hombres hay otro, vestido de blanco y con un sombrero del mismo color. Desde la perspectiva del espectador, los cañones de los fusiles esconden sus cejas.

El pelotón de fusilamiento, en contraste con el desorden caótico de las víctimas, está formado por ocho hombres que se muestran de perfil por detrás, de modo que sus caras no son visibles. Las manos con las que ejecutan la orden de disparar tampoco son visibles, con la excepción de la mano izquierda del soldado más adelantado.

La gran linterna colocada frente al pelotón de fusilamiento proyecta toda la luminosidad; la luz impacta sobre las víctimas, por lo que estas reciben la iluminación óptima, como un objetivo que no puede escapar a los soldados. 


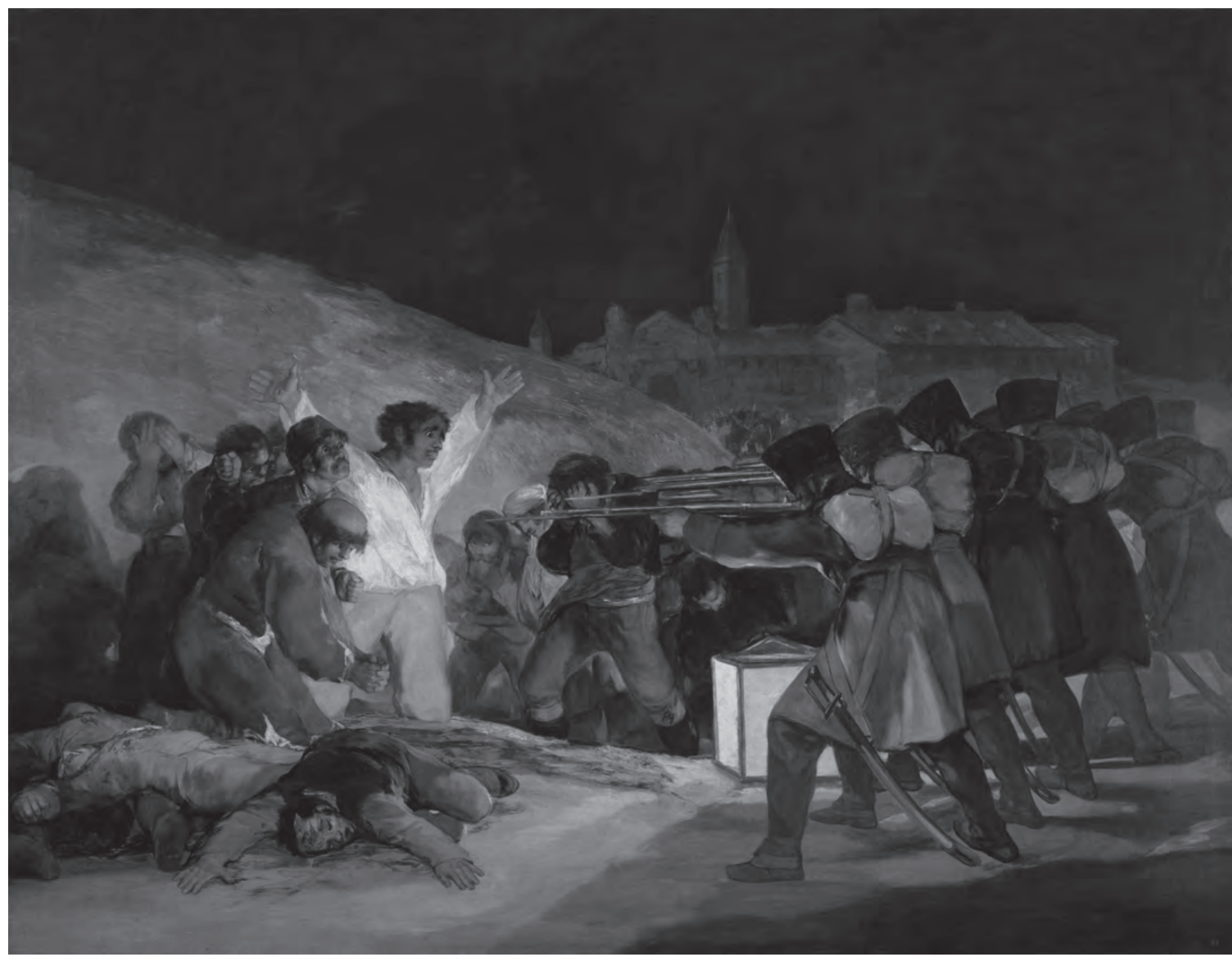

7. Francisco de Goya El 3 de mayo de 1808, 1814, óleo sobre lienzo, $268 \times 347 \mathrm{~cm}$. Museo Nacional del Prado, Madrid.
EL «DOS DE MAYO DE 1808» Y «EL TRES DE MAYO DE 1808»: ANÁLISIS COMPARADO

El dos de mayo de 1808 y El tres de mayo de 1808 se corresponden, esencialmente, con los acontecimientos históricos que ambas obras representan. Goya se informó debidamente de los combates y los fusilamientos posteriores, aun cuando probablemente no fue un testigo ocular de aquellos acontecimientos. ${ }^{41}$ Pese a ello, pudo obtener el testimonio de testigos directos: entre los insurgentes heridos cerca de la Puerta del Sol se hallaba el también pintor León Ortega y Villa, discípulo de Goya, de dieciocho años. ${ }^{42}$

Comparando las dos obras, ambas muestran vencedores y vencidos, pero en diferentes distribuciones de roles: en el primer lienzo se ve la derrota de los franceses y la victoria momen-

41. La leyenda, según la cual Goya vivía cerca de la Puerta del Sol y presenció las peleas como testigo ocular, fue refutada por Demerson, G., «Goya, en 1808, no vivía en la Puerta del Sol», Archivo Español de Arte, 30, 119, 1957, págs. 177-185.

42. Pérez de Guzmán y Gallo, J., El dos de Mayo..., págs. 655 y 707; Alía y Plana, J.M., «El primer lunes...», pág. 120; Glendinning, N., «Representaciones de la guerra de la Independencia: El dos de mayo y Los fusilamientos», en Goya. Barcelona: Galaxia Gutenberg, 2002, pág. 275. 
tánea de los españoles. Los soldados franceses y los mamelucos están evidentemente en peligro e intentan huir ante la embestida de los madrileños. En el segundo lienzo está representada la victoria de los franceses y su venganza. En El dos de mayo, Goya muestra un momento del levantamiento; en El tres de mayo las consecuencias para los españoles. Los acontecimientos representados en la primera pintura suceden en la ciudad, los de la segunda fuera de ella; los unos durante el día, los otros por la noche.

En cuanto a la elección de las armas, hay una diferencia fundamental entre los dos lienzos. En el primero los combatientes luchan cuerpo a cuerpo, armados de forma individual. Los mamelucos pelean con arma blanca, con cimitarras, que emplean contra los ciudadanos; estos se dirigen contra sus enemigos con armas cortantes y cuchillos. En este sentido, la obra se corresponde con la tradición de las pinturas de batallas en las que los combatientes individuales luchan los unos contra los otros, aunque estén agrupados. ${ }^{43}$

En el segundo lienzo, Goya reúne las modernas armas de fuego portátiles, las bayonetas, en el pelotón de fusilamiento. En él, la individualidad y responsabilidad de cada sujeto queda suspendida y se disuelve en la del grupo, puesto que el sujeto individual se convierte en una parte integral de una masa uniforme y anónima. A través de la elección de las armas Goya muestra dos tipos y fases de la guerra diferentes, la tradicional y la completamente nueva. Así, mientras que la espada individualiza al combatiente, el fusil en el pelotón lo anonimiza. El fusil es el arma de las masas, resultante de un perfeccionamiento técnico-racional. ${ }^{44}$ Los soldados franceses representados en El tres de mayo son así privados de su individualidad y responsabilidad, son deshumanizados y transformados en una máquina de matar eficiente e implacable.

\section{LA REPRESENTACIÓN DE LOS MAMELUCOS EN «EL DOS DE MAYO DE 1808»: UNA ALUSIÓN A LA RECONQUISTA}

Un rasgo particular de El dos de mayo de 1808 son los mamelucos, una aristocracia militar sujeta a sus sultanes en Egipto y Siria, ${ }^{45}$ que fueron vencidos por Napoleón el 21 de julio de 1798 en la batalla de las Pirámides. En 1801 los mamelucos, que llegaron a Francia junto con el ejército del Oriente de Egipto, eran un contingente autónomo de 240 mercenarios dentro de las tropas francesas napoleónicas. Entraron en Madrid en 1808 como miembros de la Guardia de Honor de Murat, y el 2 de mayo, 150 de ellos se hallaban en la capital de España. ${ }^{46}$

El hecho de que Goya no represente solamente soldados franceses en El dos de mayo de 1808, sino un grupo de mamelucos, fue el resultado de una decisión deliberada. Al elegir la presencia de los mamelucos Goya evitó una confrontación directa entre los españoles y los franceses, asignando a estos últimos una posición marginada en la pintura. Que Goya enfrente a los ciudadanos madrileños directamente con enemigos orientales - como representantes de Francia-puede interpretarse como una alusión a la Reconquista. La identificación de los mamelucos con los moros se corresponde con la propaganda política de la época y en muchos documentos contemporáneos son denominados «moros».

43. MünKler, H., Politische Bilder..., págs. 64-79.

44. Ibidem, págs. 73 y 75 .

45. Ayalon, D., Le phénomène mamelouk dans l'orient islamique. París: Presses Universitaires de France, 1996; HaARMANN, U., «V. Der arabische Osten im späten Mittelalter 1250-1517», en HaLM, H., Geschichte der arabischen Welt. Múnich: C.H. Beck, 2001, págs. 217-263.

46. Alía y Plana, J.M., «El primer lunes...», pág. 109. 
Así, Goya intentó desencadenar en El dos de mayo de 1808 reacciones reflejas y mecanismos de defensa de la Reconquista muy arraigados en España y transmitidos durante siglos de generación en generación, insinuando, de esta forma, una segunda invasión musulmana. ${ }^{47}$

\section{UNA VÍCTIMA ESPAÑOLA EN «EL DOS DE MAYO DE 1808» Y SU INTERPRETACIÓN}

El soldado muerto con la garganta seccionada a la izquierda del primer plano de El dos de mayo, en una postura retorcida y con los brazos extendidos hacia delante, no es un soldado francés, sino español, vestido con el uniforme de los Granaderos de Marina. ${ }^{48}$ En realidad, de esta división — de guardia el 1 de mayo de 1808 en el Gobierno Militar, situado en la Casa de Correos— solo tres soldados participaron en los combates y fueron heridos, pero ninguno de ellos murió. Por tanto, Goya transformó la realidad con la intención de producir un efecto más complejo: en el momento de la superioridad de los españoles sobre los mamelucos no solo muestra a estos como vencedores temporales, sino que también presenta, al mismo tiempo, a la víctima del combate, superando así la simplicidad de la oposición entre vencedores y vencidos, entre amigos y enemigos, porque la muerte acecha a todos los hombres, sin diferenciar el bando al que pertenezcan. Esto abre posibilidades interpretativas reveladoras respecto a la puesta en escena de las nacionalidades: los españoles están representados en El dos de mayo no solo como los vencedores, superiores en cierto momento del combate, sino también, como en El tres de mayo, como víctimas. La victoria y la derrota están por lo tanto representadas relativamente porque son absolutamente casuales. Debido a esta casualidad también su importancia se relativiza. Goya subraya este mensaje infringiendo en varios aspectos las convenciones y reglas de composición académicas tradicionales: no existe el héroe victorioso e idealizado que normalmente constituye y domina el centro de la batalla. Tampoco existe una jerarquía estricta de los representados. Evidentemente, los amigos y los enemigos son tratados por igual. Es un momento arbitrario de la batalla, elegido al azar, no un punto culminante o un momento de cambio. Se trata de un episodio, de una instantánea entre muchas. En la representación simultánea de la victoria y la derrota destaca Goya sus consecuencias: la violencia, las lesiones, las heridas, el dolor y la muerte violenta, es decir, todas las consecuencias inexorables de la guerra para los seres humanos, independientemente de si se trata de una victoria o de una derrota o de si se trata de amigos o enemigos.

\section{LA CONNOTACIÓN RELIGIOSA DE LOS ESPAÑOLES EN «EL TRES DE MAYO DE 1808»}

El tres de mayo de 1808 contiene varias referencias religiosas y teológicas. Los edificios en el fondo del lienzo representan la Iglesia. El monje con la tonsura es un servidor de esta institución. Puede, incluso, identificarse, ya que solo un sacerdote fue fusilado el 3 de mayo de 1808

47. Neuschäfer, H.-J., «Goya und die Tragödie...», pág. 454.

48. Alía y Plana, J.M., «El primer lunes...», pág. 120; Glendinning, N., «Representaciones...», págs. 274-275. 
en Madrid. ${ }^{49}$ Fue el presbítero Francisco Gallego Dávila, capellán del Real Monasterio de la Encarnación, quien fue presentado a Murat y le dijo que estaba dispuesto a morir. ${ }^{50}$

En la esquina izquierda del lienzo, una vaga sombra podría corresponder al contorno abocetado del cuerpo de una mujer. A primera vista podría ser la sombra del grupo de los hombres que van a ser ejecutados, pero cabe la posibilidad de que sea la forma insinuada de la Virgen María sosteniendo el cuerpo muerto de Jesucristo, lo que se correspondería a la representación de una Pietà. En este caso sería, también, una referencia a la iconografía cristiana. ${ }^{51}$ No obstante, la forma de la sombra es ambigua y su identidad no puede desentrañarse. Esto se pone claramente de manifiesto en la primera reproducción de la pintura. Publicada en 1867 en París —erróneamente bajo el título Le Deux Mai- en el libro Goya de Charles Yriarte, ${ }^{52}$ el dibujo lo hizo Étienne-Gabriel Bocourt (1821-1905), quien copió el lienzo de Goya el 12 de agosto de 1866, según el registro de copiantes del Museo del Prado. ${ }^{53}$ En esta primera reproducción se puede ver la silueta de una mujer, ataviada con un abrigo de cuello ancho que se lleva la mano izquierda a la cabeza. Delante de ella se acuclilla un hombre con bigote que dirige su mirada hacia los cadáveres tendidos en el suelo (ilustración 8).

Inequívocamente, sin embargo, la figura central de El tres de mayo de 1808, el hombre de pie con los brazos extendidos, representa a la Iglesia, a la que se refieren los colores blanco y amarillo de su ropa: el blanco y el amarillo son los colores heráldicos de la Iglesia católica y del Papa ${ }^{54}$ Además, el hombre, cuyo destino es la muerte, asume la postura de un Cristo crucificado, como si su cuerpo hubiera sido fijado a una cruz invisible. No solo por su actitud simboliza la figura de Cristo: ambas manos están perforadas, por lo que tienen los estigmas del Crucificado. Equiparando el que sufre injustamente con Cristo, Goya seculariza el símbolo cristiano y lo convierte en un símbolo del dolor eterno.

Por tanto, como resultado de esta múltiple codificación, los españoles, víctimas del pelotón de fusilamiento francés, pueden ser identificados como representantes del cristianismo. Dado que no hay ningún comentario de Goya al respecto, solo el contexto de la época relativo a la mentalidad de los contemporáneos podría aclarar la motivación y las razones de tal codificación cristiana. Una vez más, la intención de Goya hubiera podido ser la de abolir una imagen del enemigo, en este caso aquella que las naciones europeas crearon con relación a los españoles: es decir, la leyenda negra. La intención de Goya se corresponde, pues, con el programa de la Ilustración, que consistía en liberar al mundo de todos los prejuicios. La leyenda negra, como una arraigada imagen del enemigo, dominó en los siglos XVI y XVII la visión negativa de España en los países europeos. ${ }^{55}$ En la época de la Ilustración la leyenda negra se concretizó, en el ambiente de los ilustrados franceses, en la acusación del atraso de España en comparación

49. Alía y Plana, J.M., «El primer lunes...», pág. 130.

50. Pérez de Guzmán y Gallo, J., El dos de Mayo..., pág. 667, núm. 121; Lafuente Ferrari, E., Goya..., pág. 47 , n. 7.

51. Nordström, F., Goya, Saturn and Melancholy. Studies in the Art of Goya. Estocolmo-Gotemburgo-Uppsala: Almquist \& Wiksell, 1962, pág. 180; THомаs, H., Goya..., pág. 17.

52. Yriarte, C., Goya. Sa biographie. Les fresques, les toiles, les tapisseries, les eaux-fortes et le catalogue de l'œuvre, avec cinquante planches inédites d'après les copies de Tabar, Bocourt et Ch. Yriarte. París: Henri Plon, 1867, ilustración entre las págs. 86 y 87 .

53. Wilson Bareau, J., «Manet and Spain», en Tinterow, G.; Lacambre, G.; Roldán, D.L.; Wilson-BareaU, J., Manet/ Velázquez. The French Taste for Spanish Painting, cat. exp., 4 de marzo - 29 de junio de 2003, The Metropolitan Museum of Art, Nueva York. New Haven - Londres: Yale University Press, 2003, págs. 244-245, 249 y 245, fig. 9.76.

54. Sobre el blanco y el amarillo como colores de la Iglesia, véase ERDMANN, C., «Das Wappen und die Fahne der römischen Kirche», Quellen und Forschungen aus italienischen Archiven und Bibliotheken, 22, 1930-1931, pág. 250; TRAEGER, J., Goya. Die Kunst der Freiheit. Múnich: C.H. Beck, 2000, pág. 139.

55. El concepto leyenda negra para denominar esta imagen del enemigo fue acuñado en 1913 por Julián Juderías. PoLLMANN, J., «Eine natürliche Feindschaft: Ursprung und Funktion der schwarzen Legende über Spanien in den Niederlanden, 1560-1581", en Bosвach, F., Feindbilder. Die Darstellung des Gegners in der politischen Publizistik des Mittelalters und der Neuzeit. Weimar-Colina: Böhlau, 1992, pág. 73. Sobre la leyenda negra en general, véase HöNscH, U., Wege des Spanienbildes im Deutschland des 18. Jahrhunderts. Von der Schwarzen Legende zum Hesperischen Zaubergarten. Tubinga: Max Niemeyer, 2000, págs. 9-29. 


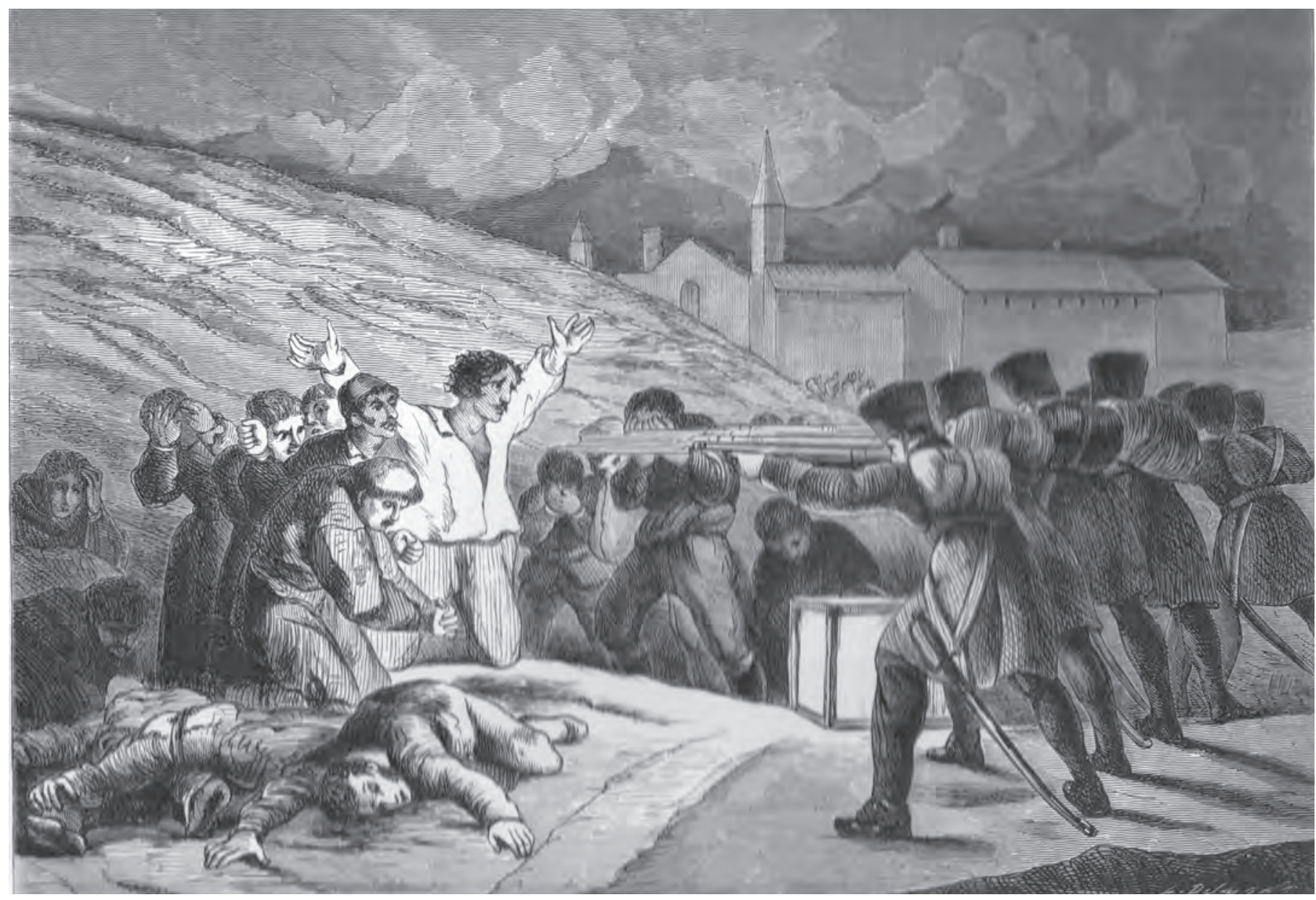

8. ÉtienneGabriel Bocourt Le Deux Mai, dibujo, en Charles Yriarte, Goya. Sa biographie. Les fresques, les toiles, les tapisseries, les eaux-fortes et le catalogue de l'ouvre, avec cinquante planches inédites d'après les copies de Tabar, Bocourt et Ch. Yriarte, París: Henri Plon, 1867 , págs. 86 y 87 . con los otros países europeos, lo que a menudo desembocó en la equiparación de España con África. ${ }^{56}$

La imagen del enemigo implícita en la leyenda negra negaba a los españoles que pudieran considerarse cristianos. ${ }^{57}$ Una de las principales acusaciones residía en el comportamiento no cristiano que tuvieron en relación con los indígenas en las colonias americanas, actitud que les equiparó a los paganos. ${ }^{58}$ Los difusores de la leyenda negra buscaron sus estrategias de justificación en la historia de la Península ibérica, considerando el origen racial de los españoles como una mezcla de antiguos cristianos, moros y judíos, lo que dio como resultado un pueblo de carácter híbrido, aspecto que explicaba el abandono de la comunidad religiosa, a diferencia de otras naciones cristianas de Europa. ${ }^{59}$ Según esta construcción ideológica, se generó una imagen de enemistad casi natural de los españoles respecto a los otros países cristianos de Europa, y así la guerra contra los españoles fue utilizada casi como una guerra de religión cristiana o una cruzada en territorio europeo. ${ }^{60}$

56. TschilschKe, C.voN, «Spanien als Afrika Europas. Zur Konjunktur einer Denkfigur im 18. Jahrhundert», en JüTTNER, S.; Steinkamp, V., Die Konstituierung eines Kultur- und Kommunikationsraumes. Europa im Wandel der Medienlandschaft des 18. Jahrhunderts. Fráncfort-Berlín-Berna-Bruselas-Nueva York-Oxford-Viena: Peter Lang, 2008, págs. $209-229$.

57. Sobre la imagen del enemigo en la leyenda negra, véase Pollmann, J., «Eine natürliche Feindschaft...»; MÜNKLER, H., Politische Bilder..., págs. 29-30.

58. Sobre el estereotipo del enemigo como adversario de Dios, véase KeEN, S., Gesichter des Bösen. Über die Entstehung unserer Feindbilder. Múnich: Wilhelm Heyne, 1993, págs. 24-32.

59. Pollmann, J., «Eine natürliche Feindschaft...», pág. 74; Münkler, H., Politische Bilder..., págs. 29-30.

6o. Pollmann, J., «Eine natürliche Feindschaft...», págs. 80, 83 y 86-9o. 
Goya refuta en El tres de mayo de 1808 la imagen del enemigo divulgada en la leyenda negra: en el lienzo los españoles no son los conquistadores que dominan y hacen desaparecer las otras naciones europeas, sino las víctimas de los otros. No son los incrédulos contra los cuales luchan los cristianos, sino que ellos mismos son los cristianos que son combatidos por los incrédulos.

En este contexto hay que destacar el efecto y la función de la tez morena y la fisonomía morisca del hombre con los brazos extendidos en El tres de mayo. Así, este hombre del pueblo no solo tiene la función de simbolizar a Cristo; debido a su similitud con un morisco, Goya modifica los roles en el segundo lienzo en comparación con el primero: en El dos de mayo son los moros los enemigos de los españoles, pero en El tres de mayo los españoles están, debido a la convivencia y la mezcla de las razas, representados por un morisco. De este modo, Goya intenta destruir o, más aún, superar, el antagonismo hacia el otro como enemigo, porque uno tiene características del otro en sí mismo. En consecuencia, se deroga la distinción entre lo propio y lo ajeno, y por lo tanto la distinción entre amigo y enemigo. La aparición de un hombre y su fisonomía no pueden ser un criterio para distinguir entre amigos y enemigos: la imagen del enemigo se destruye, porque lo esencial es el ser humano, el respeto al otro. En el primer lienzo los moros son los agresores, pero en el segundo ellos son las víctimas, si se considera al hombre con los brazos extendidos como un morisco.

\section{LA METÁFORA DE LA LUZ EN «EL TRES DE MAYO DE 1808» Y EN LA ILUSTRACIÓN}

Como fuente de luz, la lámpara en El tres de mayo de 1808 ocupa una posición central en la estructura de la pintura. La luz no representa la emanación de Dios, como la señal tradicional de su transfiguración, sino que tiene la función, completamente secularizada, de posibilitar al pelotón de fusilamiento la tarea de matar. ${ }^{61}$ La puesta en escena de la violencia requiere la modulación de la iluminación, en el sentido de focalizar la luz hacia las víctimas, exactamente en la medida en que permita a los ejecutores verlos; pero el ejercicio de la violencia requiere también la oscuridad que rodea el acto violento, hacia el cual la luz se focaliza. Metafóricamente, solo cierta cantidad de luz hace visible la violencia que se realiza, sin embargo, queda en secreto y rodeada de oscuridad. La violencia evita y necesita la luz. El claroscuro no está equilibrado, sino que el oscuro ejerce un papel predominante como expresión del oscurantismo de los ejecutores. La luz no solo sirve para ilustrar la violencia y la oscuridad, también proporciona la protección necesaria para que sus autores puedan ejercer la violencia libremente y de forma anónima. El escuadrón de la muerte de los soldados franceses se muestra como una especie de máquina ejecutoria de la muerte, totalmente deshumanizada, anónima, uniformada, orientada a un solo objetivo: la realización incondicional del mando de la ejecución.

En cuanto a los colores, el de la linterna se corresponde al de la ropa del hombre central, con su camisa blanca y los pantalones amarillos, y asimismo, debido a las condiciones de luz, ambas partes están relacionadas entre sí: la linterna ilumina al hombre con los brazos extendidos. En el siglo XVIII, la luz y su significado metafórico fueron, también en España, relacionados con las ideas de la Ilustración, lo que demuestra que la denominación Siglo de las luces se corresponde con los términos Aufklärung, Siècle des Lumières, Enlightenment o Illuminismo, uti-

61. Licht, F., Goya. Die Geburt der Moderne. Múnich: Hirmer, 2001, pág. 168. 
lizados en otros países europeos. ${ }^{62}$ El mundo opuesto a la Ilustración se representa con lo oscuro, y Goya dedica atención a esta oscuridad en su pintura, presentándola. No rechaza lo oscuro, sino que intenta evocarlo y conjurarlo en sus imágenes. ${ }^{63}$ Así, el contraste entre la luz y la oscuridad puede ser entendido metafóricamente como el contraste entre la razón vinculada a la luz y la cara oscura de los sentidos, de las pasiones o de la superstición. ${ }^{64}$

En este contexto hay que destacar, en El tres de mayo de 1808, el blanco reluciente de la camisa del hombre central y el de la linterna: el uso del blanco puro es una innovación sin precedentes en relación con la tradición académica en la pintura de la época. El uso del blanco puro - sin mezclar con otro color, lo que supondría un sombreado o al menos cierta matización del blanco-representa, absolutamente, la destrucción de un tabú.

Respecto al diseño y a la estructuración, El tres de mayo se rige de acuerdo con las reglas académicas, al menos a primera vista. Por este motivo, y como demuestra la historia de la recepción de la obra, esta ha sido considerada superior en comparación con El dos de mayo. No obstante, en cuanto al uso de los colores, Goya quebranta sin contemplaciones, como se ha dicho, todas las convenciones, desobedeciendo los usos del claroscuro académico y emancipándose del valor tradicional de los colores - porque como tales utiliza también el blanco y el negro puros-.$^{65}$ La tendencia hacia la abstracción e independencia del color se muestra también en el color casi monocromo de la roca desnuda en El tres de mayo.

Goya rompe, con la utilización del blanco puro y brillante —en la linterna y en la camisa-, no solamente cualquier convención artística, sino que pinta al español de una forma totalmente nueva, con el gesto del Cristo crucificado, en oposición al pelotón de fusilamiento de los franceses, que representó de un modo tradicional. El contraste entre lo antiguo - los francesesy lo nuevo o moderno - los españoles- es evidente. Goya invierte la repartición de la luz en $E l$ tres de mayo y consigue de esta manera otra asignación de las dos naciones -francesa y española - ante el movimiento de la Ilustración, que no se corresponde con la tradicional: iluminados son los españoles, no los franceses; estos están en la oscuridad, son los oscurantistas. Con la inversión de la asignación de la luz, como representación pictórica y metafórica de la Ilustración, Goya reacciona al mundo al revés de la situación política contemporánea.

Desde este punto de vista los franceses - artífices de la Ilustración y de la Revolución francesa - traicionaron sus propios principios e ideas; y dispararon a los españoles, quienes les habían considerado su modelo. Pero en esto radica también la esperanza de la Ilustración: los españoles la adoptan, asumen sus ideas y valores, le dan continuidad y la desarrollan, mientras que los franceses, con su política de opresión, la abandonan y la delatan. Así, son los españoles y no los franceses los que representan la innovación. El conflicto irreconciliable entre los ideales y la descorazonadora realidad se representa mediante la repartición y la metáfora de la luz en El tres de mayo. Goya otorga al pueblo español la verdad como resultado esencial de la Ilustración, de sus ideales y metas. Un pueblo que ahora representa sus legítimas pretensiones de autonomía y libertad dispuesto y decidido, como está, a luchar por ellas, incluso a costa de su propia existencia.

Ciertamente Goya utiliza también, en ambos lienzos, ciertos estereotipos, por ejemplo el del enemigo como agresor en El dos de mayo o el del enemigo sin rostro y anónimo, en El tres de mayo ${ }^{66}$ Pero lo decisivo es que modifica subversivamente estos estereotipos, relativizándolos y desvalorizándolos de tal manera que obliga al espectador a reflexionar sobre su justificación.

62. Sobre el concepto de la luz y su significado metafórico en el siglo XVIII, véase Álvarez DE MirANDA, P., Palabras $e$ ideas: el léxico de la Ilustración temprana en España (1680-1760). Madrid: Aguirre, 1992, págs. 167-210.

63. Starobinski, J., 1789. Die Embleme der Vernunft [KitTLer, F.A. (ed.)]. Múnich: Wilhelm Fink, 1988, pág. 102.

64. Ibidem, págs. 102-103.

65. Prater, A., «Goyas Schwarz. Eine Skizze», en Zaunschirm, T., Die Farben Schwarz. Viena - Nueva York: Springer, 1999, págs. 70-71.

66. Sobre estos estereotipos, véase KeEN, S., Gesichter des Bösen..., págs. 15-23. 
La estrategia de paz de Goya funciona indirecta, pero completamente, a efectos de los ilustrados franceses, poniendo de relieve en sus dos obras las constantes universales del sufrimiento humano y las consecuencias dolorosas de su política, y la deshumanización y desindividualización en la maquinaria de muerte del pelotón de fusilamiento. Así, Goya, no solamente documenta en El dos de mayo y El tres de mayo escenas singulares de determinados momentos históricos, sino que ambos lienzos son representaciones artísticas de situaciones extremas de una universalidad atemporal, sublimadas de tal manera que poseen un valor simbólico eterno. Goya sublimó las imágenes del enemigo dando cuerpo en sus pinturas a un monumento exhortatorio de validez universal y atemporal por la paz, y contra la violencia y la guerra. Con esto, ciertamente, no consiguió ganar el favor de Fernando VII y, durante décadas, los dos lienzos fueron olvidados. La posteridad los estima de otra manera que el rey al que fueron destinados. 